\title{
CONF-960421--21
}

\section{NUMERICAL ANALYSES OF REINFORCED UNDERGROUND OPENINGS SUBJECTED TO SEISMIC LOADINGS}

\section{Fei Duan}

Civilian Radioactive Waste Management System Management \& Operating Contractor

Morrison Knudsen Corporation

101 Convention Center Drive

Las Vegas, NV 89109

(702)794.5187

\section{INTRODUCTION -}

The Yucca Mountain Site Characterization Project is investigating the feasibility of locating a high-level radioactive nuclear waste repository at Yucca Mountain, Nevada. As a part of the site characterization efforts, an Exploratory Studies Facility (ESF) is being designed and constructed to provide an underground facility for research and study of the host horizon. Three types of loads, geostatic, seismic and thermal, are considered during the design analysis of ESF underground opening stability. This paper examines the potential impact of the earthquakeinduced dynamic loading on the stability of the ESF underground openings. Design and construction of the ESF consist mainly of a loop tunnel and associated test alcoves. The 7.62-meter diameter main access loop, which includes Topopah Spring North Ramp, Main Ramp, and Topopah Spring South Ramp, is being excavated by a tunnel boring machine. Test alcoves are being excavated either using drill and blast techniques or by mechanical methods.

The ESF main access loop will eventually become an access tunnel for the permanent repository if the site is determined to be suitable. It is essential to ensure long-term stability of openings by using adequate and maintainable ground support systems. The installed ground support systems need to be designed to withstand the maximum seismic events specified in design requirements. The major components of the ESF ground support systems include rock bolts, shotcrete and steel sets.

The propagation direction of seismic waves generated by earthquakes is generally random with respect to any underground structure. This feature complicates the analysis of underground openings in the rock mass behaving distinctively in compression, tensile and shear. This is especially true when certain discontinuity features such as
Saeed Bonabian

BEOEDED

Civilian Radioactive Waste Management System 2 I 1300 Management \& Operating Contractor

Morrison Knudsen Corporation

101 Convention Center Drive

OSII

Las Vegas, NV 89109

(702) 794.1870

joints, beddings and faults exist. Therefore, predicting the behavior of the underground structures that are subjected to potential seismic loadings is a very challenging engineering task. Recent advances in numerical modeling techniques enhanced by powerful, yet less expensive computers provide new avenues to deal with the challenge. For ESF design, it is essential to make sound engineering analysis of potential damage to the underground openings and associated ground support systems. As a product of the ESF design effort performed in geotechnical design analysis work, this paper only presents some of typical numerical results obtained.

\section{WORK DESCRIPTION}

To study the stability of the underground openings subjected to seismic loading, both two- and three-dimensional computer models have been constructed along the tunnel alignment. Finite difference codes $F L A C^{1}$ and FLAC3D ${ }^{2}$ as well as distinct element codes $\mathrm{UDEC}^{3}$ and $3 D E C^{4}$ are used to perform the numerical analyses. These codes are developed by ITASCA Consulting Group and have been benchmarked by the design team to meet the project requirements.

ESF openings pass through four major rock formation units: the Tiva Canyon (TCw), the upper Paintbrush Tuff (PTn), uppermost Topopah Spring (TSw1), and middle Topopah Spring (TSw2). Table 1 shows the elastic and strength properties for each unit. The best estimated ratio of in-situ horizontal to vertical stress falls within 0.25 and 0.50 . The PTn rock formation is the weakest unit. The major portion of the tunnel will be excavated in the relatively competent Tsw1 and TSw2 units. Seismic loadings are simulated after the tunnel and alcoves have been excavated under the in situ stress loading condition.

Seismic loading is applied to each computer model after the rock mass and ground support systems surrounding the 
tunnel have reached a new equilibrium stage. Viscous boundary conditions are used to prevent the outwardpropagating waves from reflecting back into the model at boundaries. The sinusoidal shear velocity wave is applied at the bottom boundary and propagates upward. This shear wave causes horizontal ground vibration (shaking) and is a leading cause of structural damage. The compressional wave in the vertical direction is treated in a similar way.

Table 1. Rock Mass Properties

\begin{tabular}{|c|c|c|c|c|}
\hline $\begin{array}{l}\text { Rock } \\
\text { Fonnation } \\
\text { Units }\end{array}$ & $\begin{array}{l}\text { Young's } \\
\text { Modulus } \\
\text { (GPa) }\end{array}$ & $\begin{array}{l}\text { Poisson's } \\
\text { Ratio' }\end{array}$ & $\begin{array}{l}\text { Cohesion } \\
\text { (MPa) }\end{array}$ & $\begin{array}{l}\text { Friction } \\
\text { Angle } \\
\text { (deg) }\end{array}$ \\
\hline $\mathrm{TCw}$ & $6.70-27.71$ & 0.2 & $1.2-3.0$ & $53-55$ \\
\hline PTn & 2.50 & 0.2 & $0.3-0.5$ & $40-44$ \\
\hline TSw1 & $5.66-18.90$ & 0.3 & $0.7-1.9$ & $41-43$ \\
\hline TSw2 & $6.37-23.51$ & 0.21 & $1.3-3.8$ & $49-50$ \\
\hline
\end{tabular}

Figure 1 shows a typical mesh refinement surrounding the opening. The rock bolts are represented by one-dimensional truss elements while shotcrete and steel sets are represented by two-dimensional beam elements with three degrees of freedom at each end of a beam segment.

\section{RESULTS}

The numerical analyses provide valuable information about the stability of the opening and the resultant loads on the structures. A sample of these results documented in the report $^{5}$ is presented in this paper. Figure 2 illustrates an input shear velocity wave underneath the model and the monitored ground vibration at the top of the model after the wave has propagated through the model. Energy dissipation due to ground damping distorts the wave shape and reduces the amplitude. Figure 3 shows comparisons in tunnel closures and load changes in ground supports after static and seismic loadings. Vertical and horizontal closures of the tunnel respond noticeably to the seismic loadings but quickly mobilize to static closures once the wave passes. There is an increase in the maximum loads in the tunnel liner due to seismic loading. Numerical results have indicated that the load changes are not significant enough to cause damage to the installed ground support systems. Numerical analyses have also revealed that seismic loading can sometimes cause the shotcrete liner to be partially in compression and partially in tension momentarily. In this regard, adequate liner fiber reinforcing is prudent, though the stress has not gone beyond either compressive or tensile strength of the liner. Different rock formations respond differently in dynamic movement to applied seismic loads.

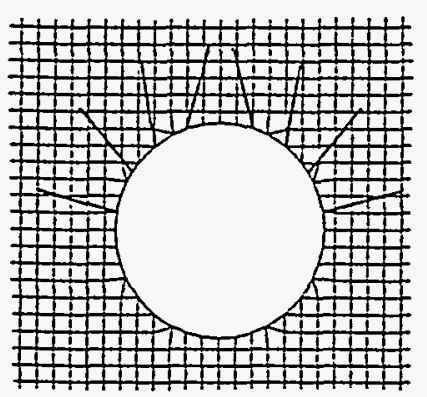
with Rock Bolt Support

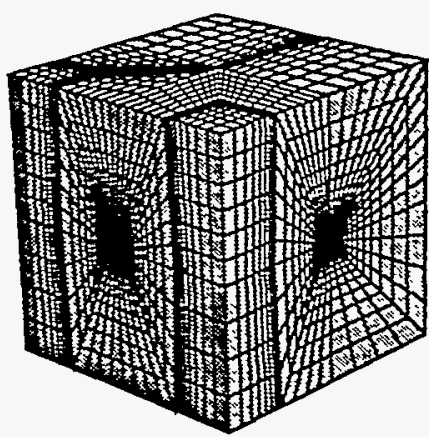

(c) An FLACID Model of TunneVAlcove Intersection (a) An FLAC Model of Tunnel

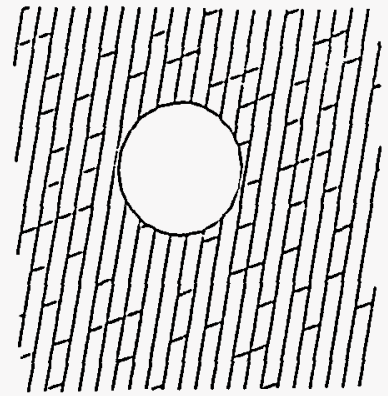

(b) A UDEC Model.of Tunnel with Joines Consedered

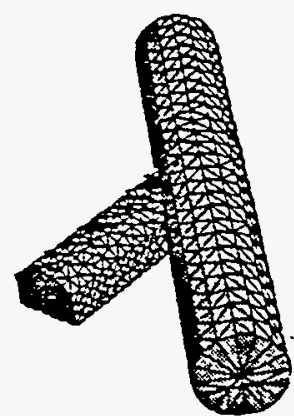

(d) A 3DEC Model of TunneVAlcove Intersection
Figure 1. Close-ups of Numerical Models for Analyses.
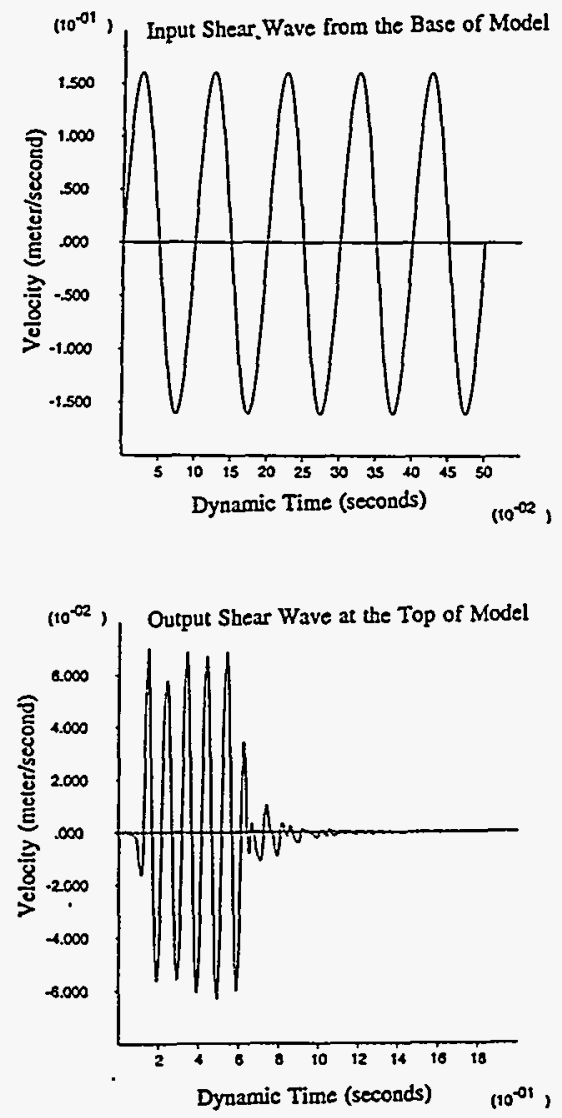

Figure 2. Simulated Seismic Velocity Waves. 

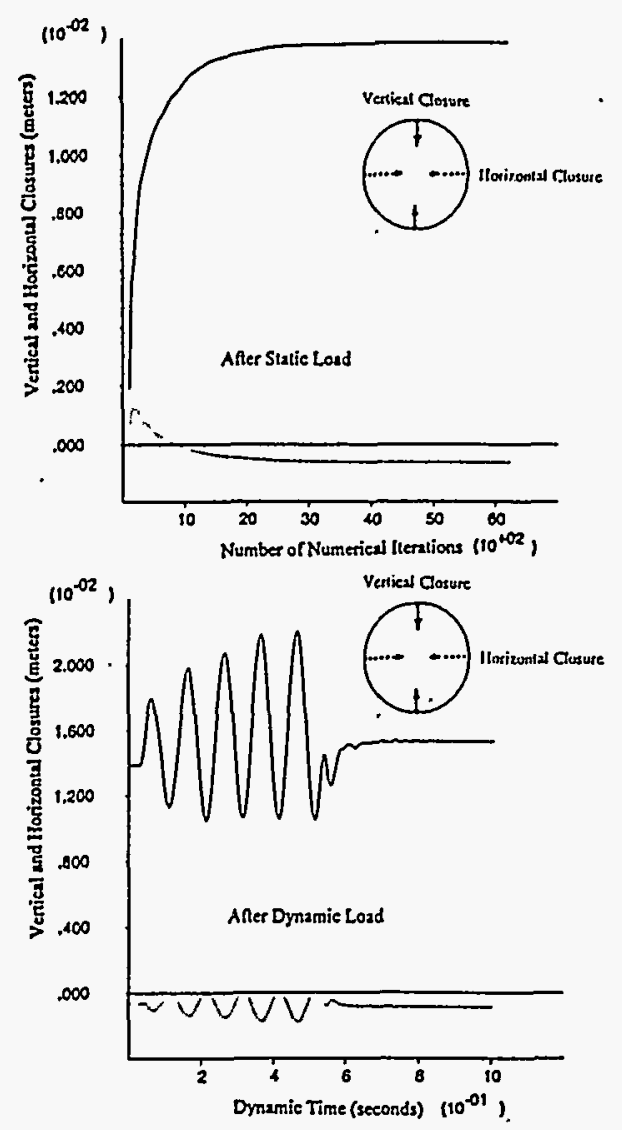

(a) Tunnel Closures

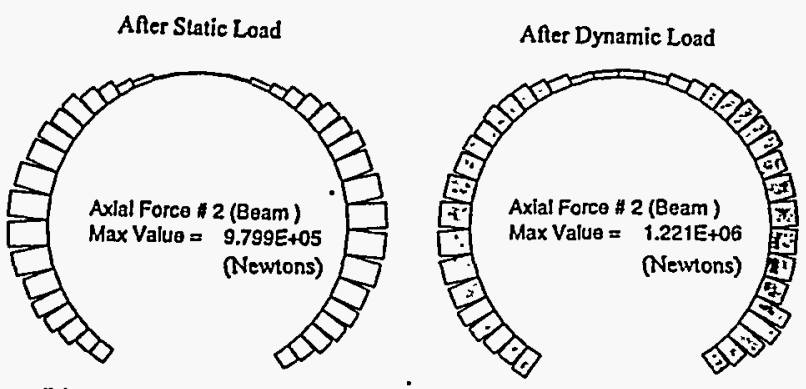

(b) Axial Force Distribution in Tunnel Lining
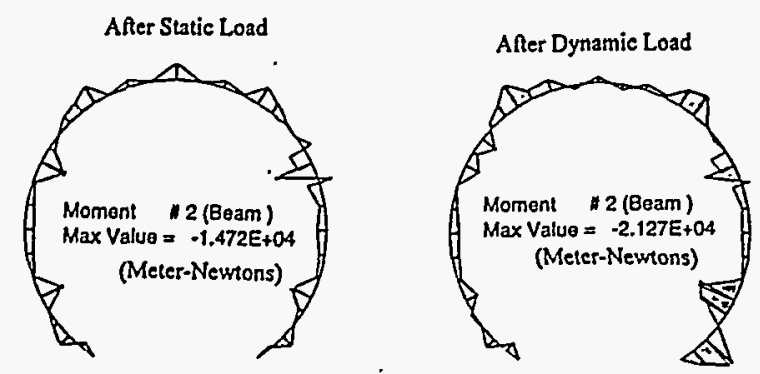

(c) Bending Moment Distribution in Tunnel Lining

Figure 3. Comparisons in Tunnel Closures and Load Changes in Ground Supports after Static and Seismic Loadings.
The tunnel experiences a maximum dynamic closure of 2 $\mathrm{mm}$ in TCW, $7 \mathrm{~mm}$ in TSwl and $12 \mathrm{~mm}$ in TSw2. The tunnel still remains stable, as incated by all three models.

\section{CONCLUSIONS AND DISCUSSIONS}

While there are no well-established analytical or empirical formulae capable of predicting the potential damage characteristics from an earthquake to underground openings, numerical modeling methods have served as a very useful engineering tool for examining the excavation stability and guiding the selection of ground support systems, bolting patterns and excavation sequence. Numerical results have also indicated that for the underground openings, the seismic wave frequency does not have a significant effect on rock displacement or loads in support elements. Such numerical responses are realistic in considering that the deep underground tunnels are confined by the surrounding rock and are, therefore, less sensitive to frequency value. Rapid and inexpensive parameter studies through numerical modeling have allowed for gaining insight into the design concerns caused by unavoidable uncertainties in geological data and material behaviors. Numerical analyses provide a foundation for design validation, which occurs through further back analysis of field instrumentation data and observations to be collected during construction.

\section{ACKNOWLEDGEMENTS}

The authors acknowledge the review made by a number of Management \& Operating staff at the Las Vegas Office.

\section{REFERENCES}

1. User's Manual, Vol. I, II, and III, Fast Lagrangian Analysis of Continua (FLAC) Version 3.2, Minneapolis, MN: ITASCA Consulting Group, Inc.

2. User's Manual, Vol. I and II, Fast Lagrangian Analysis of Continua in 3-Dimensions (FLAC3D) Version 1.0, Minneapolis, MN: ITASCA Consulting Group, Inc.

3. User's Manual, Vol. I and II, Universal Distinct Element Code (UDEC) Version 2.0, Minneapolis, MN: ITASCA Consulting Group, Inc.

4. User's Manual, Vol. I and II, 3-Dimensional Distinct Element Code (3DEC) Version 1.5, Minneapolis, MN: ITASCA Consulting Group, Inc.

5. Civilian Radioactive Waste Management System Management \& Operating Contractor, 1995. ESF Ground Support Design Analysis: DI BABEE000001717-0200-00002 REV 00. 


\section{DISCLAIMER}

This report was prepared as an account of work sponsored by an agency of the United States Government. Neither the United States Government nor any agency thereof, nor any of their employees, makes any warranty, express or implied, or assumes any legal liability or responsibility for the accuracy, completeness, or usefulness of any information, apparatus, product, or process disclosed, or represents that its use would not infringe privately owned rights. Reference herein to any specific commercial product, process, or service by trade name, trademark, manufacturer, or otherwise does not necessarily constitute or imply its endorsement, recommendation, or favoring by the United States Government or any agency thereof. The views and opinions of authors expressed herein do not necessarily state or reflect those of the United States Government or any agency thereof. 